\title{
The Contribution of Zobe Dam to the Socio-Economic Development of Makera Community Dutsinma Local Government Area, Katsina State North-Western Nigeria
}

\author{
Badamasi Jamda Saidu ${ }^{1,}$, Godwill Geofrey Jidauna ${ }^{3}$, Jamila Kira Sanusi ${ }^{3}$, Daniel Davou Dabi ${ }^{2}$ \\ ${ }^{1}$ Department of Geography, Federal University Kashere, Kashere, Nigeria \\ ${ }^{2}$ Department of Geography and Planning, University of Jos, Jos, Nigeria \\ ${ }^{3}$ Department of Geography and Regional Planning, Federal University Dutsinma, Katsina, Nigeria
}

Email address:

badamasi09@gmail.com (B. J. Saidu), uj2014pgev0164@unijos.edu.ng (B. J. Saidu)

${ }^{*}$ Corresponding author

To cite this article:

Badamasi Jamda Saidu, Godwill Geofrey Jidauna, Jamila Kira Sanusi, Daniel Davou Dabi. The Contribution of Zobe Dam to the SocioEconomic Development of Makera Community Dutsinma Local Government Area, Katsina State North-Western Nigeria. International Journal of Environmental Monitoring and Analysis. Vol. 7, No. 3, 2019, pp. 75-82. doi: 10.11648/j.ijema.20190703.13

Received: May 21, 2018; Accepted: June 12, 2019; Published: September 20, 2019

\begin{abstract}
This study examines the contribution of Zobe dam to the socio-economic development of Makera Community Dutsinma LGA, Katsina State north-western Nigeria. The study identified types of socio-economic activities supported by the dam and their impact. Total of 392 questionnaires was administered to adults target population using stratified random sampling technique. Descriptive and inferential statistics were used to analyze the data. Findings revealed main economic activities supported by the dam are farming $(60.46 \%)$, fishing $(30.10 \%)$, domestic water supply $(5.52 \%)$ and livestock watering (3.057). The positive contributions of the dam include an increase in the availability of social amenities and resident's standard of living. Specific impacts were increased income, increased crop yield, increased farm sizes, commercial fishing and increased access to water supply sources. The survey also revealed the dam is a major pull-factor with $79.59 \%$ respondent's decision to settle in the area influenced by the dam. The negative impacts were; occasional floods that erode crops, farmlands, the introduction of new pest and spread of water associated diseases (schistosomiasis, malaria, and typhoid in decreasing magnitude). ANOVA test showed no significant difference in literacy level, occupation and water use among residents. Analysis of water quality to determine the impact of activities was recommended.
\end{abstract}

Keywords: Development, Socio-economic, Contribution, Dam

\section{Introduction}

Water is not only a commodity which is directly used by man but it is often the mainspring for extensive economic development, an essential element in man's aesthetic experience, and always a major formative factor of the physical and biological environment which provides the stage for his activities [1]. While the benefits of dam projects can be worthwhile, any interruption of natural processes brings social, environmental, and economic impact. Water management activities, particularly irrigation, played a central role in the development of the earliest known civilizations in valleys of Tigris and Euphrates, Nile, Indus, and Yellow Rivers [2]. The importance of water to man cannot be overemphasized. However, there are great differences in water availability among regions and supply through time as a result of both seasonal variation and interannual variation. Most often this has been responsible for shaping human settlements. In northern Nigeria for instance, water availability influenced the pattern of human settlements with water availability and population density having a reciprocal relationship [3].

This variability in water availability over the years has resulted in the construction of reservoirs, dams being the major of such reservoirs. A dam is a hydraulic structure of fairly impervious material built across a river to create a reservoir on its upstream side for impounding water for various purposes [4]. [5] noted that dams represent one of the 
methods of developing water resources by man and the best strategy for averting the effects of perennial drought and means of solving human problems of water storage in the drylands of the world. According to [6] 1.1 billion people are without a reliable drinking water supply. While development encompasses factors on which welfare depends, socioeconomic development is a general advancement of a given society to a higher level of welfare or well-being which includes both material and nonmaterial elements [2]. Water serves as input in many human activities such as essential biological functions, a basic element of social and economic infrastructure, and natural amenity contributing to psychological welfare [7].

In Nigeria, dam construction is considered synonymous with development and economic progress by many. This includes; food security, local employment, skills development, rural electrification and expansion of physical and social infrastructure (roads, schools, etc). The World Commission on Dams (WCD) [8] observed that construction of dam can provides employment for local communities, incentives for businesses and setting up of enterprises at dam sites. This is because modern dam development is driven by politics, economics, and energy demand. The Zobe Dam was constructed by the Federal Government of Nigeria in 1983 meant to supply $50 \%$ of domestic water to Katsina State and support irrigation farming in the Dutsinma area. Despite its completion 34 years ago, it is not used for domestic water supply to Katsina town. The crux of the matter is absence of data on the dam's contribution to Makera community located very close to it. Hence, this study is aimed at identifying the socio-economic activities supported by the dam and how they affect the lives of residents of the area.

\section{Literature Review}

There have been debates between two poles of those who see dams to have made significant contribution to human development, and those who recognized it as social and ecological disasters [7]. Positive contributions of dams have also been reported in various parts of the world. [9] reported impacts of Traveston dam in Queensland to improvement in competitiveness of industries due to water supply that attract additional labor and capital to the region. According to [10] the impact of Peshawar dam Pakistan are increased crop yield, increased number of livestock, a significant increase in revenue generated from crops, shift from traditional to market-oriented crops and improved water table that results in better well recharge compared to water shortages before the dam. Besides [11] reported socio-economic benefits of Kariba dam on the life of "Tonga and We" people in diversification of the economy, improved standard of living, acquisition of new skills and improved productivity. Significant income was recorded by farmers from agriculture around Gallito Ciego dam, Peru [12] and up to $837 \%$ increase around small dams in rural Pakistan [13]. In Ghana, small dams play crucial role in the production of market vegetables e.g onions, pepper, tomatoes, shallots and carrots
[14]. The construction of Bui dam Ghana according to [15] leads to improvement in local infrastructure (road network, drinking water, health \& education facilities), and creation of job opportunities. In terms of water supply, [16] reported the impact of Doma dam to include; provision of potable water, the creation of employment through fishing and farming activities.

Conversely, negative impacts of dams have also been recorded through man's history. [17], observed dams' constructions lead to the destruction of natural habitats and decreased woodland resulting to a reduction in species diversity and adverse effects on wildlife communities that result in a reduction of hunting and associated uses. Medical herbs are also lost, decreased forest leading to decreased timber production and attractiveness for recreationist [17]. According to [18] when new large volumes of water are created, the risk of disease e.g schistosomiasis malaria, yellow fever, river blindness, typhoid fever and liver fluke infections etc in tropical countries rises sharply. The Gezira Irrigation Scheme in Sudan increased the prevalence of schistosomiasis, malaria and yellow fever [19]. Snails, intermediate host of Schistosomiasis, was found in $90 \%$ dams in Nigeria by [20] and concluded that dams contribute to the spread, endemicity, and incidence of Schistosomiasis in host communities. The Chalillo dam Central America has not contributed positively to local economy due to flooding, destruction of ornamental plants, a bad odor which renders the river unswimmable and stoppage of fishing certain species (tilapia) due to high mercury levels [21]. The presence of Usman dam Abuja studied by [22] revealed no significant improvement in the infrastructural provision, high cases of water-borne diseases, and loss of farmland. These led to a loss of occupation and income sources which accounted for the poor standard of living. The communities' occupational structure was changing from farming and fishing to artisanship and trading due to fishing restriction and shrinking of agricultural land. In the same way, [23] reported the impact of Shiroro hydropower dam on the riparian communities to includes; distorted socio-economic growth manifested in loss of certain fish species, dismal fall in productivity of small-scale farming and fishing, destruction of houses and loss of farmland.

However as purpose of dams vary, the impact also differs with location and time. Therefore, some dams have both positive and negative impacts. While [24] reported the displacement of over 44, 000 people, and loss of fertile and grazing lands due to construction of Kainji Lake in Niger State, [25] noted positive socio-economic impact of the same Kainji dam at Lokoja, Kogi State to increased availability of large expanse of floodplain which enhanced agricultural production leading to higher income level of farmers. The work of [26] reported negative effects of Lagdo dam Republic of Cameroon to include; the spread of water-borne diseases, displacement of settlements, and reduction of farmlands and grazing areas. Others were siltation of river bed, frequent flooding, and reduction in flow which constrained fishing activities. While the positive impacts 
were improvement in welfare of the surrounding farmers, improvement in water supply for domestic, irrigation, and survival of livestock. In Plateau State Nigeria, [27] reported positive impact of Laminga dam to includes; increase in income generating ventures, boosting of commercial activities, provision of domestic and industrial water supply and recreational activities that contributed to better livelihood of residents, while the negative impacts were increased prevalence of water-borne diseases and reduction in land value due to fear of flood.

\section{The Study Area}

Zobe Dam is located in Makera, a rural settlement $75 \mathrm{~km}$ south of Dutsinma headquarters of Dusinma LGA, Katsina State. The dam has rivers Karaduwa and Gada as its tributaries and stores up to 177 million cubic meters of water during rainy season. The reservoir formed by the Dam covers 4,500 hectares of rocky land and it is about 2.7 kilometers long flowing north-westward to the Sokoto Basin. The study area is located between latitudes $120^{\circ} 20^{\prime} 34.62^{\prime \prime}$ and $120^{\circ} 23^{\prime} 27.48^{\prime \prime}$ North of the Equator and longitudes $70^{\circ} 27^{\prime} 57.12^{\prime \prime}$ and $70^{\circ} 34^{\prime} 4.68^{\prime \prime}$ east of the Greenwich Meridian. Dutsinma LGA is bounded by Kurfi and Charanchi LGAs in the North, Dan-Musa and Matazu in the South, and Kankia and Safana LGAs in the East and West respectively (Figure 1). Makera community has estimated population of 19,629 in 2017 based on growth rate of $2.8 \%$ [28]. It has mean annual rainfall of between $600-800 \mathrm{~mm}$, mean onset of 18 May - 7 June, Late-onset dates of 9-29 June, mean cessation dates of 27 October, and early cessation of 27 Sept. -7 Oct. [29]. The area has two marked seasons, the dry and wet, and these are influenced by movement of the InterTropical Convergence Zone (ITCZ). From May the ITCZ moves northward, the warm, wet South-West which bring rains dominate the scene up to October. However, from November, the ITCZ moves southward and the cold dry North-East Trade Wind characterized by dryness and dust dominate the scene till April. Movement of this wind also affects temperature; the coldest months are December and January with mean low temperature of $25^{\circ} \mathrm{C}$, while the hottest months are March and April with mean high temperature of $35^{\circ} \mathrm{C}$.

The vegetation is Sudano-Sahelian with predominantly grass and few scattered trees. However, gallery forest is found along rivers. The trees grow long tap roots and thick back that make it possible to withstand the long dry season. The existing vegetation is a function of many years of human interference e.g cutting of trees for fuelwood, cultivation, grazing, bush burning etc. The soil of the region is mostly sandy-loam, reddish color, with medium fertility and supports crops like millet, beans, and groundnut. Along with water bodies and riversides, the soils are loamy and support the cultivation of maize, cotton, guinea corn and vegetables such as tomato, pepper, and onion. Fertile land played a great role in growth and development of the region, which serve as a center of cash crops production especially cotton and groundnut and this attracted farmers, animal rearers and merchants [30]. The dam provides water for both domestic water supply and agricultural purposes especially irrigation farming. Residents are farmers, but some rear animals and engage in fishing. Agrochemicals (fertilizers, pesticides, and herbicides) are potential contaminants of the dams' reservoir. The Hausa-Fulani are the largest and dominant group that occupies the area. Other ethnic groups such as the Igbo and Beriberi are also found.

\section{Materials and Methods}

Socio-economic impact analysis examines how an act of development could potentially impact a community, the social and economic aspects of the potential impact, and the community attitude towards the changes. According to Bird [21], measuring the aggregate impact of a project is a challenging task. The most straightforward approach is to measure the impact on each specific sector separately such as economy e.g., income, social, income distribution, and environment, and thereafter add them together to obtain the total effect [12].

Data for this study were obtained through the administration of questionnaires, focus group interviews and observations. Data on water-related diseases was obtained from the only public healthcare facility in the community. A pilot survey to check the operational effectiveness of the survey instruments was conducted. Anderson [31] notes that a pilot study is a 'pre-test' that checks the feasibility of a planned survey. Familiarization, support, and co-operation of traditional rulers were sort during this exercise. Questionnaires were pretested, scored for clarity and ambiguous questions modified. Three community informants namely; chairman of fishermen, chairman of irrigation farmers, and youth leader were identified and engaged in the conduct of the fieldwork. The study targeted adult males who are household heads. This is because the norm in typical Muslim dominated settlement in northern Nigeria with the exception of food preparation places the responsibility of all family needs on the husband who is recognized as the household head. The survey was designed to capture $10 \%$ household population which only one person was interviewed in a household. But the household population of Makera community was not available. Therefore, the population of the community was converted to the household population by dividing 19,629 with 5 which is the standard household size in Nigeria according to [28]. This gave 3, 926 as household population and $10 \%$ of the household population gave 393 as sample size. 


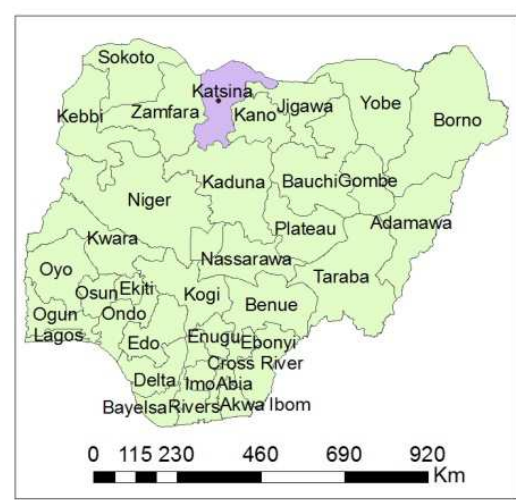

$7^{\circ} 0^{\prime} 0^{\prime \prime E ~} 7^{\circ} 30^{\prime} 0^{\prime \prime E} \quad 8^{\circ} 0^{\prime} 0^{\prime \prime E} \quad 8^{\circ} 30^{\prime} 0^{\prime \prime E} 9^{\circ} 0^{\prime} 0^{\prime \prime E}$

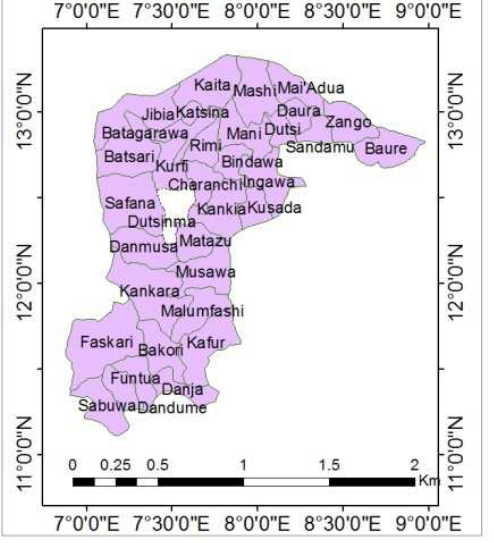

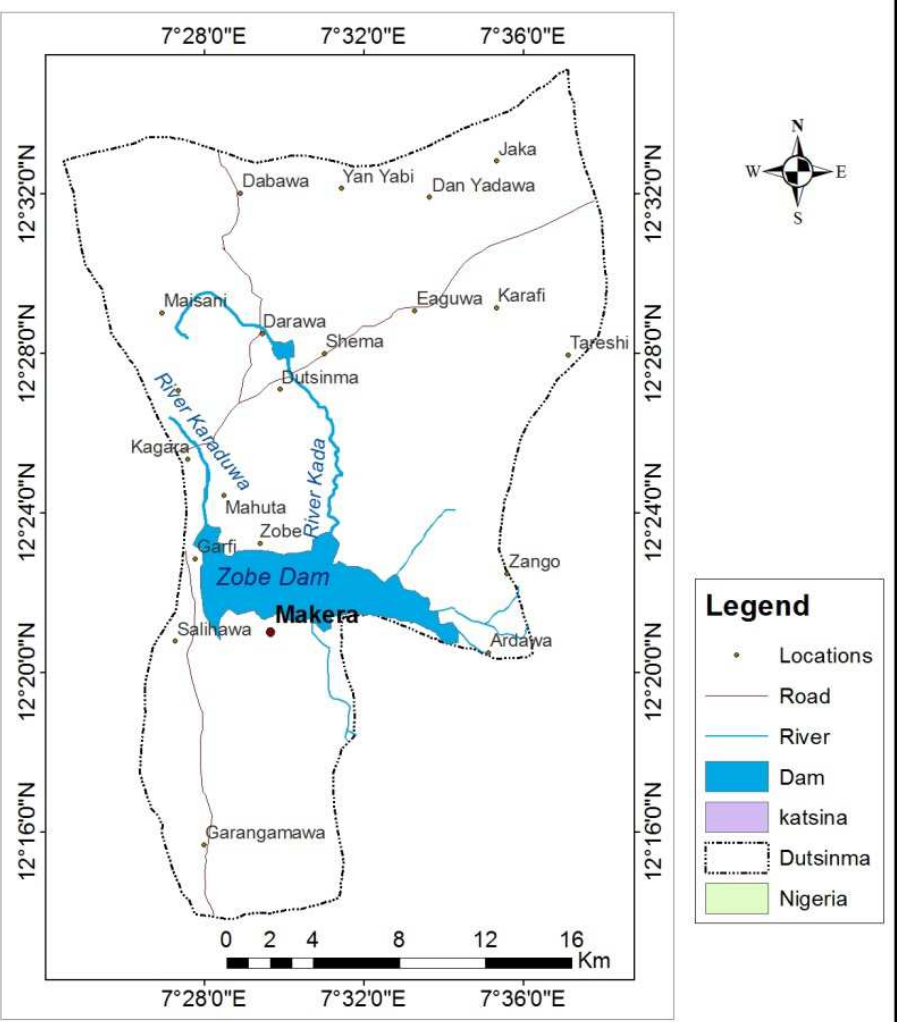

Source: Department of Geography and Planning, University of Jos, Plateau State, Nigeria.

Figure 1. Dutsinma showing Zobe Dam (Insert: Nigeria and Katsina State).

Therefore, 393 questionnaires were designed with 37 questions to capture the contribution of the dam (direct \& indirect benefits derived by residents and/or problems encountered) as well as the socio-demographic aspects of the population. The stratified random sampling technique was used. The stratification was to ensure even spread, while randomization was to give every household equal chances of inclusion in the survey. For stratification, the study area was divided proportionately into four (north, south, east \& west), and 98 questionnaires administered in each. For randomization, it involved the use of a 'lucky dip' in which all households within each stratum were dipped and those that pick yes included in the survey. The questionnaires were administered by research assistants on an individual voluntary basis in the form of a 10-minutes long structured interview. Each interview began with an introduction to the research project and its purpose. Verbal delivery of the questionnaires to respondents was used, and this method according to Bird [21] ensured questionnaires are not rushed. Four focus group discussions, one in each of the strata were held. The data were analyzed using descriptive and inferential statistical tools. The descriptive statistics range from tables, percentages, graphs, and charts, while Analysis of Variance (ANOVA) was used to test the research hypothesis.

\section{Results and Discussion}

\subsection{Gender, Age Distribution and Marital Status of Respondents}

The study had $88.78 \%$ male respondents with only $11.22 \%$ females. It observed males contribute more to family income than females and this may be due to the Hausa/Fulani culture and religion with $100 \%$ population of the area being Muslims may have also played a significant role. Age wise, 34.63, $41.33 \%$ and $23.98 \%$ of respondents fall within age groups $21-30,31-40$, and above 40 respectively. The result revealed respondents aged between $21-30$ and $31-40$ constitutes $76 \%$ which are active population fully engaged in income activities of farming and fishing in the area. Majority of respondents $70.92 \%$ are married, $16.3 \%, 6.12 \%$, and $6.12 \%$ are single, divorced and widows respectively. The high marital status of respondents is another typical characteristic of Muslim dominated settlements in northern Nigeria.

\subsection{Educational Level of Respondents}

Seventy-three percent $(73 \%)$ of respondents do not 
understand the English language. This supports our earlier claim (as a limitation) that the literacy level is very low among inhabitants of the area (see table 1)

Table 1. Educational Status of Respondents.

\begin{tabular}{lll}
\hline Level & Frequency & \%age \\
\hline Primary & 66 & 16.84 \\
Secondary & 86 & 21.94 \\
Tertiary & 20 & 5.10 \\
Quranic & 221 & 56.22 \\
Total & 392 & 100 \\
\hline
\end{tabular}

Source: Field Work, 2016

\subsection{Occupation of Respondents and Dam Water Uses}

The major occupation of the people of Makera is farming and this reflects the predominant occupation of rural dwellers in Nigeria (Figure 2). While some residents' combine two or more income generating activities such as farming and fishing etc, focus group discussions revealed all the civil servants in the area are also engaged in farming to augment their income. Farming, fishing, and animal rearing are strongly supported by the dam (Figure 3). Water uses of the dam's reservoir follow the same pattern with the occupation of residents. The analysis of variance (ANOVA) showed no significant difference between educational level, occupation, and type of water use among residences at $95 \%$ confidence level.

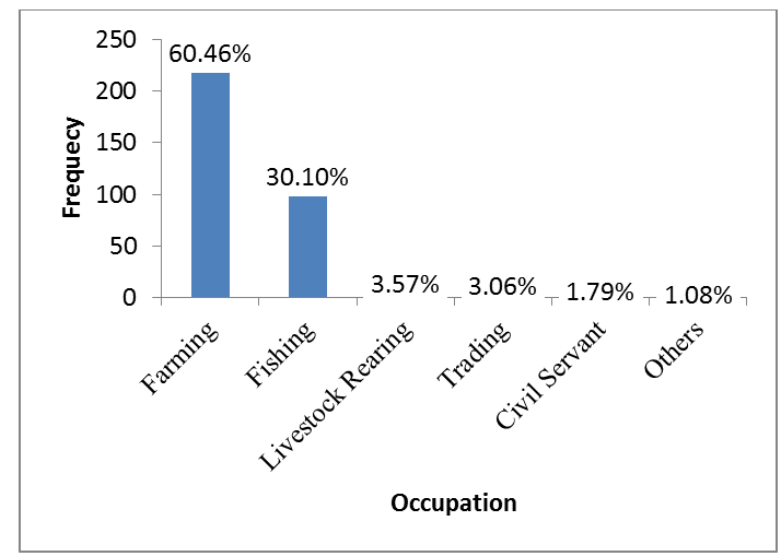

Figure 2. Occupation of Respondents.

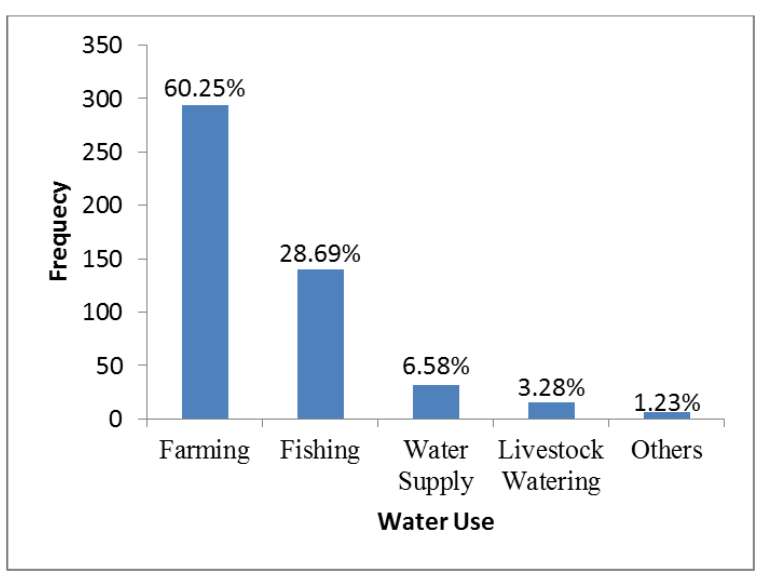

Figure 3. Zobe dam water uses by respondents.

\subsection{Farming Practices and Irrigated Crops Grown in Makera Community}

Combining rain-fed and irrigation is the highest farming practice among farmers in Makera Community. Of the 290 respondents who are farmers, 168 practice both rain-fed and irrigation farming, while 76 and 46 practice exclusively rainfed and irrigation farming respectively (Figure 4). Only 16\% of farmers practice exclusive irrigation and this may not be unconnected with the high demand of irrigation system which requires extra efforts and huge resources. These tasks include; regular watering of crops, tilling of the farm, adjustment of canals and movement of pipes during watering. Besides, money is required for purchase and maintenance of pumping machines, pipes, fueling of the machine and high cost of hiring laborers. The major crops grown through irrigation in the area are; maize, vegetables, rice etc (Figure 5).

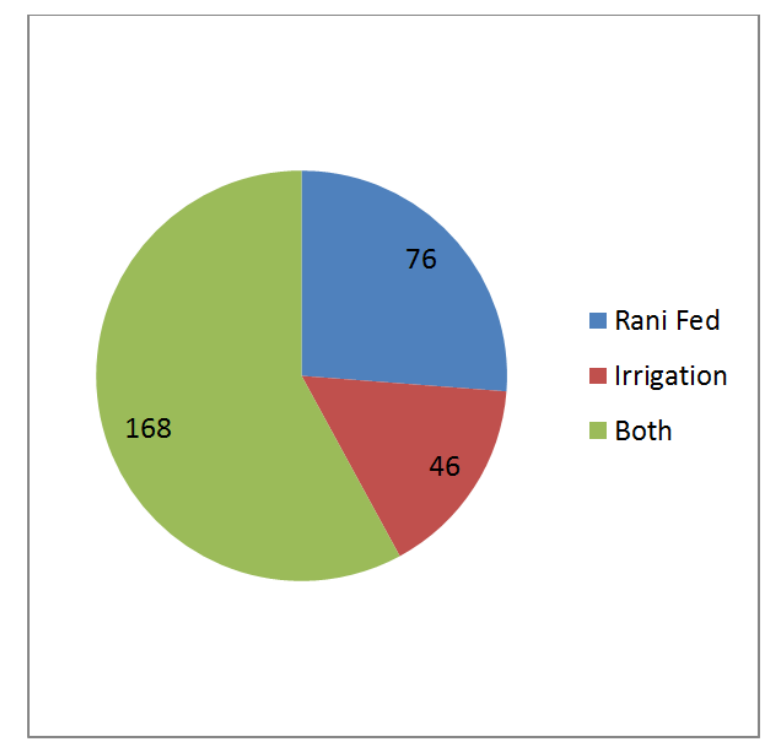

Figure 4. Farming practices in Makera.

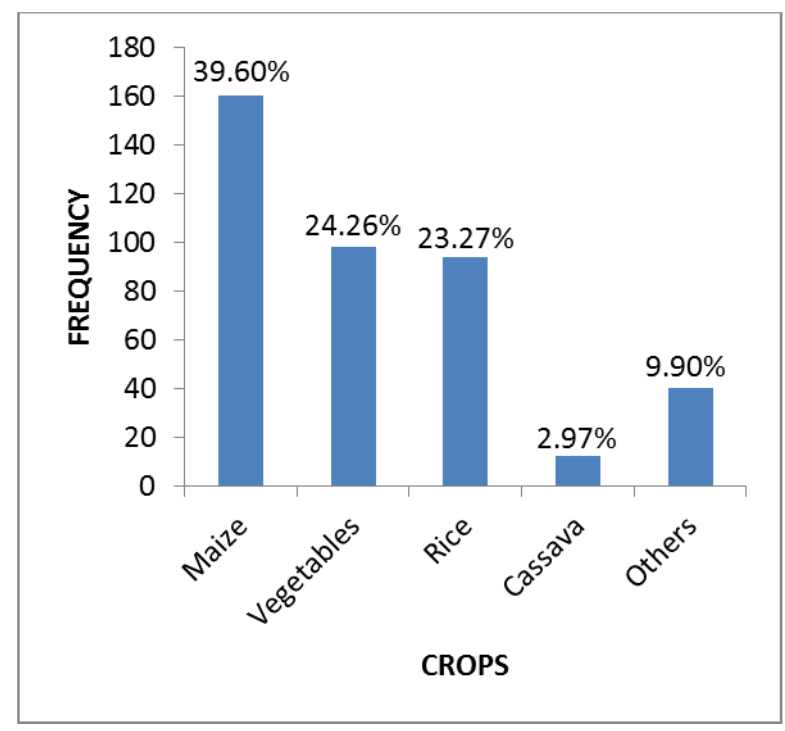

Figure 5. Irrigated crops in Makera Community. 


\subsection{Dam's Influence on Farm Size and Crop Yield}

Farm size is very important in determining the output of farm produce [13]. The survey revealed $82.19 \%$ farmers increased farm sizes sequel to dam construction which provided water for irrigation during dry and drought periods. Respondents who increased farm sizes were those whose farms are located close to the dam. Irrigation and increase of farm sizes led to increased crop output (table 2)

Table 2. Reason for increased harvest by farmers.

\begin{tabular}{lll}
\hline Reason & Frequency & \%age \\
\hline Irrigation & 130 & 30.81 \\
Increase & 80 & 18.96 \\
Applicationoffertilizer & 124 & 29.38 \\
Applicationofpesticide & 82 & 19.43 \\
Others & 6 & 1.42 \\
Total & 422 & 100 \\
\hline
\end{tabular}

Source: Field Work, 2016.

\subsection{Fishing and Domestic Water Supply Before and After Dam Construction}

Fishing is another income generating activity supported by the dam. One hundred and fifty $(38.86 \%)$ respondents are fishermen. Focus group discussions revealed less than $10 \%$ current fishermen were engaged in fishing before dam construction. This implies $90 \%$ of fishermen started fishing after dam construction. The numbers of fish catch per day per fisherman vary from five to 350 , with the rainy season having more fish than dry season. Income per day per fisherman ranges between N1, 500 to N7, 000, while the majority of fishermen $96 \%$ (144) and 4\% (6) does it for commercial purposes.

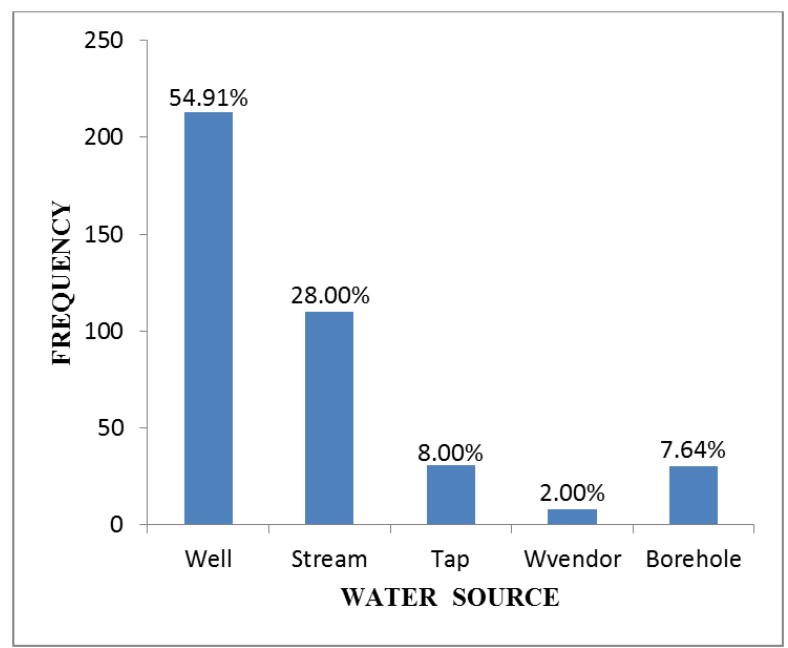

Figure 6. Domestic water supply before dam construction.

Hand dug wells and streams were the major sources of domestic water supply in Makera with $54.91 \%$ and $28.00 \%$ respectively before Zobe Dam construction. But after the dam construction, dug wells and streams dropped to $34.43 \%$ and $7.6 \%$ in that order, while boreholes and tap rose from $7.64 \%$ to $43.33 \%$ and $8.00 \%$ to $11.72 \%$ respectively (Figures
$6 \& 7$ ). The observed slide shift from dug wells and streams to boreholes and tap water may be due to increase in residents' income which in turn requires more protected water sources for domestic uses. The constant supply of water for livestock is one of the economic benefits of the dam. The percentage of respondents in all the strata who own some livestock is ninety-two percent $(92 \%)$.

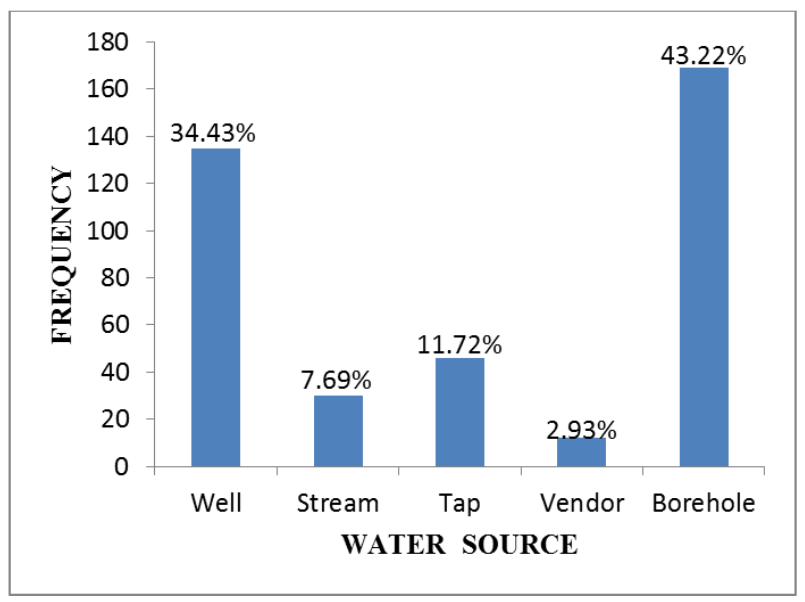

Figure 7. Domestic water supply after dam construction.

\subsection{Infrastructure and Resident's Perception of Dam Water Quality}

The dam water quality assessment was based on respondent's perception. While $314(80.10 \%)$ rated the dam water quality as good, $16(15.31 \%)$ rated it as excellent. It is safe to state that the dam is a major pull factor for people who settled in Makera. This is because over $70 \%$ of respondents decision was influenced by the dam. The survey revealed road, water supply, school, and electricity are the major infrastructures benefited by the community which were constructed during or after dam construction which is believed to be influenced by the dam (Figure 8).

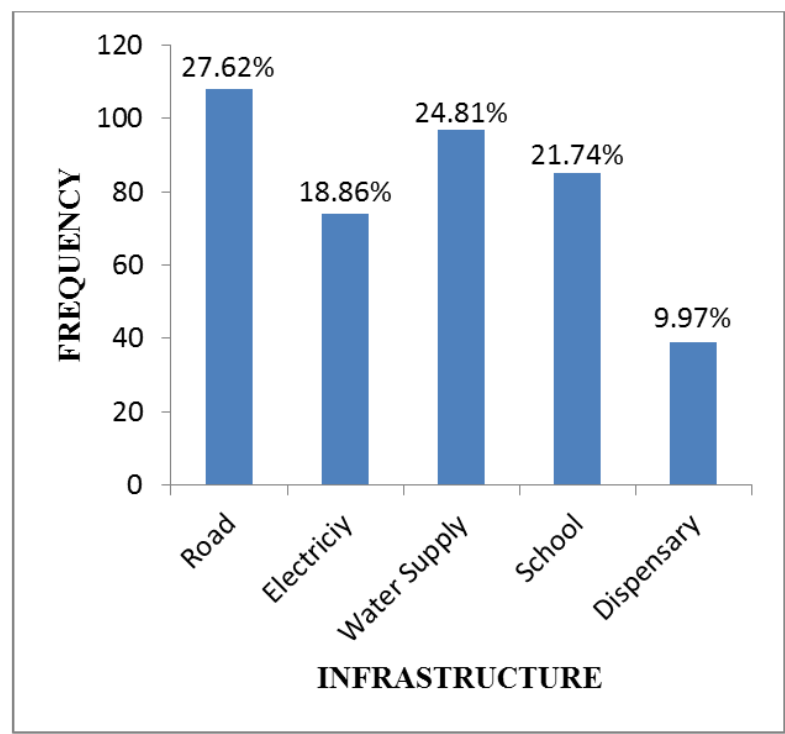

Figure 8. Infrastructures Benefited by Makera Community. 


\subsection{Negative Impacts of the Dam}

Floods are common with dams, especially where the dams are not adequately maintained or have construction defects. It's also associated with the emergence of a new pest in some environments. Of the 292 respondents who experienced a decrease in crop yield at some points, $29.45 \%, 35.62 \%$, $10.27 \%$ and $6.85 \%$ attributed it to floods, pest, erosion and animal invasion respectively. While floods affected farms downstream, erosion affected those located closed to the dam. The dam has become a breeding ground for disease vectors such as snails and mosquitoes which causes schistosomiasis and malaria respectively. Available data on water-related diseases obtained from the only Primary Health Clinic in Makera showed malaria and typhoid have the highest prevalence with $254(43.20 \%)$ and 148 (25.17\%) (see Table 3).

Table 3. Water-related Diseases in Makera Community.

\begin{tabular}{lll}
\hline Disease & Frequency & \%age \\
\hline Cholera & 40 & 6.80 \\
Schistosomiasis & 46 & 7.82 \\
Typhoid & 148 & 25.17 \\
Malaria & 254 & 43.20 \\
Others & 100 & 17.01 \\
Total & 588 & 100 \\
\hline
\end{tabular}

Source: Field Work, 2016.

\section{Conclusion and Recommendations}

The study revealed the Dam has both positive and negative impacts on Makera Community. The positive contribution includes; provision of reliable source of water with equitable access for domestic water supply, irrigation, fishing and livestock watering. The dam serves as a source of attraction for people and infrastructures such as road, school, and electricity. The equitable access is shaped by the preconceived notion that water is a free commodity or "gift" and each member of the community has the right of access. The negative impacts are occasional floods and erosions that washed away crops, farmlands, and spread of water-related diseases such as malaria, typhoid, schistosomiasis etc. Therefore, there is need to enhance the beneficial contributions and minimize the adverse impacts of the dam. In the light of the above, the following recommendations and suggestions for further studies were proposed thus;

i. The water quality of the dam should be analyzed to determine its suitability for human consumption.

ii. The provision of improved infrastructure for waterbased recreation and tourism is necessary to enhance the benefit of the dam.

iii. The dam can also be used for development of a mini hydroelectric power plant project to augment the national power grid and contribute to the production of clean energy.

\section{Critique of the Study}

The study could not analyze water samples from the dam to determine whether the level of individual water quality parameters (physical, chemical \& biological) was in agreement with respondent's perception which over $90 \%$ rated the water quality as good for drinking. This is because the quality of any water body, especially the chemical and microbial components cannot be known unless it is analyzed using appropriate instrument and methods.

\section{References}

[1] Adebola, A. O., Garba, I. K., Ahmed S. A., Muhammed, M. \& Kudu, D. (2014). The socioeconomic characteristics of communities at the downstream sector of Jebba dam, Nigeria. Ethiopian Journal of Environmental Studies \& Management, 7 (1), 1-12.

[2] Cox, W. E. (ed.)(2010). The role of water in socio-economic development. Report of the International Hydrological Programme-11 Project. UNESCO: France.

[3] Nyong, A. O. \& Kanaroglou, P. S. (1999). The influence of water resources and their location on rural population distribution in North Eastern Nigeria. Journal of Environmental Science 3 (1), 46-54.

[4] Guvele, C. A. (2011). Gains from crop diversification in the Sudan Gezira scheme. Agricultural System, 70 (1), 319-333. https://doi.org/10.1016/S0308-521X(01)00030-0

[5] Butu, A. W., \& Mshelia, S. S. (2014). Municipal solid waste disposal and environmental issues in Kano Metropolis, Nigeria. British Journal of Environmental Sciences, 2 (2), 1026. From: www.ea.journals.org

[6] Yuksel, I. (2013). Dams and hydropower for sustainable development. Energy Sources Part B-Economics Planning and Policy, 4 (1), 100-110. Doi: $10.1080 / 15567240701425808$.

[7] Uyigue, E. (2013). Dams are unrenewable. Community Research and Development Centre (CREDC) Nigeria: Benin City. 1-19. From:

http://credcentre.org/Publications/Dams_are_unrenewable.pdf

[8] WCD (2002). Dam and Development. A New Framework for Decision Making. London: Earthscan publication.

[9] Wasimi, S. A. (2010). Planning for a large dam project: The case of Traveston Crossing dam. Water Resources Management, 24 (12), 2991 - 3015. Doi: 10.1007/s11269010-9591-2.

[10] Wajid, A., Usman, A., Khan, M. K., \& Ali, A. C. (2013). Socio-economic impact of small dams on local vicinity: A case study of aza Khel Dam Peshawar. Global Journal of Management and Business Research Economics and Commerce, 13 (5), 32-39. From: http://creativecommons.org/licenses/by-nc/3.0/

[11] Kaluba, K., \& Mukupe, H. (2000). Socio-economic benefits of the Kariba dam. In Tumbare, M. J. (Ed.). Management of River Basins and Dams. The Zambezi River Basin. A. A. Balkema: Rotterdam/Bookfirlds. 318pp. From: http://www.tandf.co.uk/libsite/productInfo/journals/

[12] Chavez, H., Nadolnyak, D., \& Saravia, M. (2013). Socioeconomic and Environmental Impact of Development Interventions: Rice Production at the Gallito Ciego Reservoir in Peru. International Food and Agribusiness Management Association, 16 (1), 1-16. From: www.pejeza.gob.pe 
[13] Khan, M. T., Islam, M., Chattha, T. H., \& Hayat, R. (2011). Impacts of mini dams on the socioeconomic development of farmers of the rainfed region. Journal of Agriculture and Social Sciences, 7 (4), 124-130. From: http://www.fspublishers.org

[14] Ernest, Nicholas \& Ephraim (2014). Development of small dams and their impact on livelihoods: Cases from northern Ghana. African Journal of Agricultural Research, 9 (24). 1867-1877. DOI: 10.5897/AJAR2014.8610.

[15] Peter, B. O., Kwadwo, O., Edmond, A. A., Albert, A., \& Àngel, N. M. (2016). The impacts of dams on local livelihoods: A study of the Bui Hydroelectric project in Ghana. International Journal of Water Resources Development, $\quad 32 \quad$ (2), 286-300. DOI: 10.1080/07900627.2015.1022892.

[16] Yusuf, Y, O., \& Akashe, A. A. (2014). The Doma dam and its socio-economic implication in Doma Local Government Area of Nasarawa State. Best: International Journal of Humanities, Arts, Medicine and Sciences (BEST: IJAMS), 2 (4), 87-98. From: http://www.bestjournals.in/submit-paper.php

[17] Mudzengi, B. K. (2012). An assessment of the socio-economic impacts of the construction of Siya Dam in the Mazungunye area: Bikita district of Zimbabwe. Journal of Sustainable Development in Africa, 14 (4), 1-27. From: http://www.jsdafrica.com/Jsda/Vol14No4-Summer2012B/PDF/ Assessment of the Socio-Economic Impacts. Boycen Kumira Mudzengi.pdf

[18] Kirchherr, J., \& Charles, K. J. (2016). The social impacts of dams: A new framework for scholarly analysis. Environmental Impact Assessment Review, 60. 99-114. https://doi.org/10.1016/j.eiar.2016.02.005

[19] Issam, A. W. M. (2012). The Impact of Water Borne Diseases on Rural Development in Sudan: Study of Malaria in Gezira Irrigated Agricultural Scheme. 9-54. From: http://ssm.com/abstract/=2003373

[20] Uyigue, E. (2005). Dams and Livelihood. The problems of parasitic diseases in communities hosting Dams in Nigeria. Society for Water and Public Health. From: protection.etiosa@swaphep.virtualactivism.net.

[21] Bird, E. (2012). The Socioeconomic impact of hydroelectric dams on developing communities: A case study of the Chalillo Dam and the communities of the Macal River Valley, Cayo District, Belize, Central America. Environmental Studies Electronic Thesis Collection, 14. from: $\mathrm{http}: / /$ scholarworks.uvm.edu.envstheses
[22] Fanan, U., James, I., \& Olarewaju, O. (2012). SocioEconomic Considerations at the Usman Reservoir Abuja, Nigeria. Frontiers in Science, 2 (6), 169-174. DOI: 10.5923/j.fs.20120206. 06 .

[23] Usman, A., \& Ifabiyi, I. P. (2012). Socio-economic analysis of the operational impacts of Shiroro Hydropower Generation in the Lowland Areas of Middle River Niger. International Journal of Academic Research in Business and Social Sciences, 2 (4), 57-76. From: www.hrmars.com/journals

[24] Mabogunje, A. (1973). Kainji. A Nigeria man-made Lake Socio-Economic Conditions. Nigerian Institute of social and economic research (NISER). Nigeria: Ibadan press Ltd.

[25] Shuaibu, K. (1995). The Socio-Economic Impact of Kainji Dam: A Case Study of River Niger at Lokoja, Kogi L. G. A, Kogi State. Unpublished B. Sc Project, Department of Geography. Ahmadu Bello University, Zaria.

[26] Toro, S. M. (1997). Post construction effects of the Cameroonian Lagdo Dam on the River Benue. Water and Environment Journal, 11 (1), 109-113. DOI: 10.1111/j.17476593. 1997. tb00100.x.

[27] Vivan, E. L., Umuze, A., Ali, Y., Antipas, G. R., \& Danjuma, A. K. (2015). Impact of Lamingo dam on the socio-economic activities of the people in Jos area of Plateau State, Nigeria. Case Study Journal, 3 (12), 32-43. From: $\mathrm{http}: / / w w w . c a s e s t u d i e s j o u r n a l . c o m$

[28] NPC (2006). Final results of 2006 population census of Nigeria. From: http://population.gov.ng/coreactivities/surveys/dataset/2006-phc-priority-tables/

[29] Olaniyan, I. O., Agunwamba, J. C., \& Ademiluyi, O. J. (2010). Assessment of Aquifer Characteristics in Relation to Rural water supply in parts of northern Nigeria. Research, 2 (3). 22-27. From: http://www.sciencepub.net/researcher

[30] Jidauna G. G., Ndabula, C., Saidu, B. J., Oyatayo, T. K., Dahiru, M. K., Dabi, D. D., \& Oche, C. Y. (2016). Adaptation and mitigation to water stress in Safana local government headquarters of Katsina State, Nigeria. International Journal of Natural Resource Ecology and Management, 1 (3), 99-106. Doi: 10. 11648/j.ijnrem. 20160103. 15.

[31] Anderson, A. J. B. (2000). Interpreting data: A first course in Statistics. London: Chapman \& Hall. From: http://www.worldcat.org/oclc/540888071 